\title{
Political Influence and Cost vs. Benefit of CEO Duality: Evidence from Post-IPO Performance in China
}

\author{
Heli Wang ${ }^{1}$, Lijun $\mathrm{Xia}^{2}$, Veicheng Yu${ }^{3}$ \\ ${ }^{1}$ Lee Kong Chian School of Business, Singapore Management University, Fort Canning Park, Singapore \\ ${ }^{2}$ Antai School of Economics and Management, Shanghai Jiaotong University, Shanghai, China \\ ${ }^{3}$ Faculty of Business, City University of Macau, Macau, China
}

Email address:

hlwang@smu.edu.sg (Heli Wang), ljxia@sjtu.edu.cn (Lijun Xia), vcyu@cityu.edu.mo (Veicheng Yu)

\section{To cite this article:}

Heli Wang, Lijun Xia, Veicheng Yu. Political Influence and Cost vs. Benefit of CEO Duality: Evidence from Post-IPO Performance in China. International Journal of Economic Behavior and Organization. Vol. 5, No. 1, 2017, pp. 1-7. doi: 10.11648/j.ijebo.20170501.11

Received: November 19, 2016; Accepted: December 22, 2016; Published: February 10, 2017

\begin{abstract}
Investigating the post-IPO performance of Chinese firms, we empirically examine the moderating effect of political influence in the cost vs. benefit analysis of CEO duality (the arrangement for the CEO to chair the board). We find that, on average, post-IPO performance is positively associated with CEO duality. Meanwhile, such a positive association is less pronounced for state-controlled firms, for the firms in regulated industries, and for the firms with politically connected CEOs. Our findings suggest that, the higher is the extent of political influence, the benefit of CEO duality is less likely to outweigh the cost of CEO duality. As for the implication for policy-makers, the evidence also suggests that the proposal asking all listed firms to separate the role of CEO from board chairman may need more careful consideration.
\end{abstract}

Keywords: CEO Duality, Political Influence, Stewardship Theory, Agency Cost

\section{Introduction}

The separation of management and ownership control is a fundamental feature of modern public corporations [5] [23] [22], but at the same time potentially induces an agency problem. Considering such a potential problem, separating the role of CEO from board chairman is commonly regarded as essential to effectively monitor managerial conduct. If not being well monitored by the board, a CEO may seek for his or her own interest at the firm's expense, e.g., setting certain compensation scheme in favor of himself or herself [16], [44]. Thus, the agency theory suggests a negative effect of CEO duality upon firm performance. But, on the other hand, such a perspective has been long criticized by the scholars who emphasize the stewardship role of a firm's CEO [11] [12]. The stewardship perspective argues that a CEO is a good steward of corporate assets and thus generally behaves in the firm's best interests. Accordingly, CEO duality enables the firm's leadership to be unambiguous and results in unified and efficient decision-making. Therefore, contrary to what the agency theory does, the stewardship theory predicts a positive association between CEO duality and firm performance. As for empirical evidence so far, the findings both in the United States [6] [15] and in international settings [29] are quite mixed. A potential explanation is that while both theories are relevant, the cost vs. benefit of CEO duality may substantially vary across different types of firms. For example, Boyd has suggested that the CEO duality-firm performance relationship depends on environmental dynamism and complexity [6]. With a high extent of environmental uncertainty, a high extent of decentralization may be less favored [8], and unified decision-making would be critical for success. Built on Boyd's work [6], recent evidence indeed documents a positive moderating effect of environmental uncertainty [29].

Prior contingency-based studies mainly focus on the situations in which unified decision-making is supposed to add value. But to more comprehensively understand the CEO duality-firm performance relationship, the factors influencing the agency cost caused by CEO duality should be also taken into account. This study specifically considers the agency cost of CEO duality by empirically examining how political influence affects the CEO duality-firm performance relationship. We argue that political influence mitigates competition (the competition which the firm faces in the 
market, and the competition which the CEO faces from other managers within the firm), and hence the agency problem due to CEO duality would be more pronounced.

The argument above is explored using the context of Chinese IPO (initial public offerings) firms. Due to China's unique transitional economic environment, the extent of political influence substantially varies across firms. Such a unique setting allows us to empirically examine multiple indicators of political influence. In addition, the IPO represents a transition point in a firm's development. The governance mechanisms, including the arrangement for CEO and chairman, are supposed to be formalized at the time of the IPO. Using post-IPO performance helps clarify that any association found reflects the effect of CEO duality upon firm performance, not the effect of firm performance upon whether to adopt CEO duality, and hence mitigates to a large extent the potential concern for reverse causality when other measures are used [15].

\section{Literature and Hypotheses}

\subsection{CEO Duality and Post-IPO Performance}

Since 1990, the Chinese government has encouraged state-owned enterprises to go public with one of the objectives to improve their operating efficiency. Such IPOs not only raise financial capital, but also place the corresponding firms under market scrutiny to facilitate establishing more effective management and governance systems. Later, an increasing number of non-state firms have also made IPOs with the objective to raise funds for growth, or to increase market visibility.

Chinese IPO companies generally have considerable autonomy in determining whether the role of CEO and board chairman would be combined or split [29]. In addition, several internal corporate governance mechanisms, such as the schemes of performance-based compensation and independent directors, are potentially available to listed firms. However, other governance mechanisms are generally not well developed in China [9]. For example, the stock or option based performance compensation scheme is rare, and the ratio of top management's cash compensation to that of average employees is very low when compared to their Western counterparts [7]. Furthermore, monitoring by independent directors is often ineffective because few laws or regulations support their independence. As a result, whether the CEO has a dual role as the board chairman is likely to inordinately affect the corresponding Chinese firm's corporate governance [21], and it is arguably a major determinant of the agency problem which the firm would face.

As for which one of the agency theory and the stewardship perspective matters more, prior studies on Chinese firms show mixed findings regarding the association between CEO duality and various financial performance measures [29] [39] [36] [41] [42]. Scholars generally agree that although, in China, CEO duality has important implications for listed firms, whether it is supposed to be positively or negatively associated with firm performance is still far from being clear, either conceptually or empirically.

\subsection{Political Influence and Competition}

Although the direct relationship between CEO duality and firm performance in China may be still unclear, it is possible to tease out some specific conditions in which the benefit would be less likely to outweigh the cost of CEO duality, or vice versa. In this paper, we go beyond prior studies to explore the potential role of political influence in affecting the agency cost caused by CEO duality.

According to standard economic theory, competition leads to efficient resource allocation. As a result, this gives survival pressure to the firms with serious agency problem. Scholars have thus viewed competition as a powerful force to mitigate agency problem between owners and managers [3] [37] [20], [33] [31]. It has been documented that competition can be an effective mechanism to reduce management slack, once managers are under pressure in a competitive environment [14] [20] [26] [33]. For example, competition increases the threat of takeover or liquidation which forces managers to focus on cost reduction [31].

Competition thus functions as a substitute for formal corporate governance mechanisms. Giroud \& Mueller [17] have shown that internal mechanisms of corporate governance are relatively unimportant in highly competitive industries. For example, executive equity ownership, as a long-term incentive, is perceived to be an effective mechanism in corporate governance [19]. Meanwhile, more competitive industries tend to be characterized by weaker incentive-based managerial compensation [1] [24].

In this paper, it is argued that political influence potentially mitigates the competition which the firm faces in the market, and accordingly lowers down the pressure which the corresponding manager faces.

Furthermore, similar to what is argued by Maskin, Qian and $\mathrm{Xu}$ [25], and Shleifer [32], the competition between managers within a firm may also matter. If a top manager is politically connected, he or she may face less competition or less challenge from his or her colleagues, and hence has less pressure to do his or her best, or less pressure not to pursue his or her own interest.

\subsection{Industry Regulation, Political Connection and State Ownership}

In this section, we discuss the potential effect of industry regulation, top manager's political connection and state ownership upon the association between CEO duality and firm performance.

Industry Regulation. Due to China's unique economic environment, the government imposes certain restrictions on some industries. Such regulation typically imposes entry barriers which reduce competition [10]. This can have the effect of protecting inefficient and unreliable incumbent enterprises. Heavy regulation also inhibits the development of market disciplinary forces [37]. Hence, the CEO of a firm in a 
regulated industry faces less pressure externally from the market, and the monitoring by the board would be more important with the absence of market competition.

In addition, when an industry is regulated, the extent of uncertainty (the change in market situation) is also greatly reduced, and hence quick response would be less required [3] Meanwhile, facilitating quick response to the change in market situation is an important benefit of CEO duality. To further clarify this viewpoint, it is argued that, when there is information asymmetry, the cost to identify and the cost to communicate become critical [38], especially for the communication between a firm's CEO and the board, and for the board to evaluate the CEO. Whether such costs are high or low can be one of the determining factors in the trade-off between CEO duality and CEO-chairman split. Presumably, it is costly for two parties with a big gap in information held or in capabilities to communicate with each other, or for the one with relatively inferior information or capabilities to evaluate the other. Indeed, empirical evidence shows that the higher the extent of board members' inferiority in abilities to the CEO, the more likely for the CEO to chair the board [43]. Based on a similar logic, relative to one in a regulated industry, a firm's CEO in an unregulated industry may be more likely to have private information (which the board may be ignorant of) regarding the firm's future prospect and hence regarding what needs to be done for the firm. The cost for such a CEO with private information to communicate with the board (to persuade the board) can sometimes be too high for the firm to quickly respond to the change in market situation.

In sum, we hence hypothesize:

H1: The association between CEO duality and firm performance would be less likely to be positive (more likely to be negative) for the firms in regulated industries.

Top Manager's Political Connection. The Chinese government may explicitly or implicitly induce a firm to appoint a politically connected CEO, with the objective of tightly controlling the corresponding firm and expropriating rents [13]. From a social perspective (or the government's viewpoint), a firm is usually explicitly or implicitly asked to (or at least expected to) satisfy not only its own need but also social need [18] [28]. A politically connected manager could pursue social objectives which the government desires at the shareholders' expense, and accordingly decrease firm value [34] [35].

While a politically connected manager could also be considered as a valuable asset if such an appointment is intended for the firm to gain access to production factors or capital resources [27], the presence of such connection reduces the extent of competition, especially the extent of internal competition between the corresponding manager and others. If politically connected, a top manager may face less competition from his or her colleagues. Suppose the competition between a firm's managers matters, the agency cost problem due to CEO duality can be exacerbated, if the corresponding CEO is politically connected. In sum, we hence hypothesize:
H2: The association between CEO duality and firm performance would be less likely to be positive (more likely to be negative) for the firms with politically connected CEOS.

State Controlled or Not. The early development of private ownership in China occurred during the 1980s. It marked a drastic departure from the government policy which prohibited private property ownership since 1949 [21]. The primary objective of developing such non-state ownership is to increase competitive pressure on state-owned enterprises, to increase the overall efficiency of China's economy.

Managers in Chinese non-state firms are often obstructed by difficulties in accessing capital and certain production factors [27]. Such a situation gives them much pressure as they strive to improve firm performance. State-controlled firms, in contrast, benefit from directed lending, and can be bailed out by the government. As a result, CEOs in state-controlled firms do not have the same concerns as those in non-state firms, and thus the agency cost caused by CEO duality in state-controlled firms is likely to be higher. In sum, we hence hypothesize:

H3: The association between CEO duality and firm performance would be less likely to be positive (more likely to be negative) for state-controlled firms.

\section{Methodology}

\subsection{Sample}

Our sample covers the Chinese IPO firms which issued domestic shares (so-called A-shares) between 1993 and 2003. The reason to include domestic shares only is that those shares issued to foreign investors, termed B-shares or $\mathrm{H}$-shares, have different regulatory environments.

After excluding the ones lacking required data, the final sample is composed of 769 IPO firms which constitute $63 \%$ of all firms issuing A-shares from 1993 to 2003.

\subsection{Measure of Data}

Post-IPO Performance. If the stock market is efficient, then the anticipated effect of CEO duality on performance should be incorporated in the issuing price. This consideration would make the effect of CEO duality on post-IPO stock performance unclear. However, this is not a serious concern in China because there is almost always a limited supply of IPO shares [13]. Therefore Chinese IPOs are typically oversubscribed. As a result, CEO duality is unlikely to influence Chinese firms' IPO pricing decisions. Consistent with the argument above, we do find no significant IPO pricing differential between the firms with and the firms without CEO duality. Furthermore, the lack of short-term efficiency in China's capital market suggests that long-run post-IPO performance better captures the effect than a short-run measure. This recommends our examining post-IPO performance using stock returns over a 1-, 2- and 3-year period. Specifically, post-IPO performance is measured by 1-, 2- and 3-year cumulative abnormal market-adjusted stock returns (CARs) calculated on the basis of monthly returns 
starting from the first month after the IPO date. The market returns were the equally weighted returns for all common stocks traded on the two mainland Chinese stock markets. The reason for firm performance to be measured by stock performance instead of accounting performance is that the former is more directly linked to shareholders' wealth and is less likely to be manipulated relative to the latter [2].

CEO Duality. 1 if the firm's CEO also chairs the board and 0 if not [4] [15] [30]. The corresponding data were hand-collected from the IPO prospectuses.

Industry Regulation. We code the firms in the industry categories of Mining (B), Power, Gas and Water (D), Transportation and Storage (F), Finance and Insurance (I) and Real Estate (J) as 1, and others as 0, following Fan et. al. [13].

Top Manager's Political Connection. 1 if the firm's CEO or chairman has been employed by a political agency such as the government or the military (not just as a soldier), and 0 if otherwise, following the criteria adopted by Fan et. al. [13]. Such data were hand-collected from the "Profile of Directors and Senior Managers" section of the firm's IPO prospectus.

State Ownership. Ownership information is available in the IPO prospectus since 2001, the first year in which the firms were required to report their ultimate owners. For IPOs prior to 2001, we follow previous studies, e.g. [40], to treat the ultimate owner as being the same as that reported in the 2001 annual report unless there is evidence of a change in the controlling owner.

In addition, we also include in our analyses several control variables considered to influence post-IPO performance, including the share ratio of the largest owners, market to book ratio, leverage (debt-to-sales ratio) and firm size (the natural logarithm of total assets), the same as Fan et. al. [13]. Except for hand-collected ones, all other data were collected from the China Stock Market and Accounting Research (CSMAR) database.

\section{Empirical Findings}

\subsection{Preliminary Results}

Table 1 shows the sample distribution in terms of industry regulation, top manager's political connection and ownership type. For the IPO firms whose CEO and chairman were not the same person, $85.1 \%$ of them were in unregulated industries, $62.8 \%$ of them were without politically connected top managers, and $15.1 \%$ were not state controlled. However, for the firms with CEO duality, these three numbers were $90.6 \%$, $75.9 \%$ and $19.5 \%$, respectively. Taken together, such results seem roughly consistent with our arguments.

Table 1. Sample Distribution by CEO Duality, Industry Regulation, Top Manager with Political Connection, and Ownership Type.

\begin{tabular}{|c|c|c|c|c|}
\hline & \multicolumn{2}{|c|}{ CEO and Chairman Separated } & \multicolumn{2}{|c|}{ CEO Duality } \\
\hline & \# of Obs. & Proportion (\%) & \# of Obs. & Proportion (\%) \\
\hline Firms in Unregulated Industries & 428 & 85.1 & 241 & 90.6 \\
\hline Firms in Regulated Industries & 75 & 14.9 & 25 & 9.4 \\
\hline Firms without PC Top Mgr & 316 & 62.8 & 202 & 75.9 \\
\hline Firms with PC Top Mgr & 187 & 37.2 & 64 & 24.1 \\
\hline Non-state Controlled Firms & 76 & 15.1 & 52 & 19.5 \\
\hline State Controlled Firms & 427 & 84.9 & 214 & 80.5 \\
\hline
\end{tabular}

Table 2 shows mean comparison tests relating CEO duality to post-IPO performance. For the firms without political connected top managers, CEO duality is significantly positively related to all three post-IPO performance measures. On the other hand, for the firms with political connected top managers, there is no significant performance difference between the firms with and without CEO duality. A similar pattern applies to the distinction between the firms in regulated and in unregulated industries, and between the firms which are or are not state controlled. Overall, as a preliminary univariate test, the results summarized in Table 2 tend to support the proposed hypotheses.

Table 2. Mean Comparison Tests -- the Effect of CEO Duality on Firm Performance.

\begin{tabular}{|c|c|c|c|c|c|c|c|c|c|}
\hline & \multicolumn{3}{|c|}{ One-year Post-IPO Performance } & \multicolumn{3}{|c|}{ Two-year Post-IPO Performance } & \multicolumn{3}{|c|}{ Three-year Post-IPO Performance } \\
\hline & $\begin{array}{l}\text { CEO and Chairman } \\
\text { Separated }\end{array}$ & $\begin{array}{l}\text { CEO } \\
\text { Duality }\end{array}$ & Diff. & $\begin{array}{l}\text { CEO and Chairman } \\
\text { Separated }\end{array}$ & $\begin{array}{l}\text { CEO } \\
\text { Duality }\end{array}$ & Diff. & $\begin{array}{l}\text { CEO and Chairman } \\
\text { Separated }\end{array}$ & $\begin{array}{l}\text { CEO } \\
\text { Duality }\end{array}$ & Diff. \\
\hline $\begin{array}{l}\text { Firms in Unregulated } \\
\text { Industries }\end{array}$ & -0.02 & 0.05 & $0.07 * *$ & -0.01 & 0.09 & $0.10 * *$ & -0.06 & 0.02 & $0.08+$ \\
\hline $\begin{array}{l}\text { Firms in Regulated } \\
\text { Industries }\end{array}$ & 0.12 & 0.09 & -0.03 & 0.15 & 0.07 & -0.08 & 0.17 & -0.02 & -0.19 \\
\hline $\begin{array}{l}\text { Firms without PC Top } \\
\text { Mgr }\end{array}$ & 0.00 & 0.08 & $0.08 * *$ & 0.01 & 0.13 & $0.12 * *$ & -0.04 & 0.08 & $0.12 *$ \\
\hline Firms with PC Top Mgr & 0.00 & -0.02 & -0.02 & 0.01 & -0.06 & -0.07 & -0.01 & -0.15 & $-0.14^{*}$ \\
\hline $\begin{array}{l}\text { Non-state Controlled } \\
\text { Firms }\end{array}$ & 0.01 & 0.08 & 0.07 & 0.01 & 0.23 & $0.22 *$ & -0.01 & 0.24 & $0.25^{*}$ \\
\hline State Controlled Firms & -0.01 & 0.05 & $0.06+$ & 0.01 & 0.05 & 0.04 & -0.03 & -0.03 & 0.00 \\
\hline
\end{tabular}

$* * \mathrm{p}<0.01, * \mathrm{p}<0.05,+\mathrm{p}<0.10$ for $\mathrm{t}$-tests of mean difference. 


\subsection{Multivariate Tests}

Table 3 presents the results of the multivariate tests. The OLS regressions with robust standard errors were applied to mitigate any potential heteroskedasticity. Please note that the IPO year dummies are included in the regression model as control variables, but for simplicity, the results for those dummies are not reported. Models (1)-(5), (6) -(10), and (11)-(15) show the results when one-year post-IPO performance, two-year post-IPO performance, and three-year post-IPO performance are used as the dependent variable, respectively. Models (1), (6) and (11) present the results without the interaction between CEO duality and each proxy for political influence. Models (2)-(4), (7)-(9) and (12)-(14) present the results with the interaction terms included. Taking into consideration possible overlapping effects of the three proxies, Models (5), (10) and
(15) include all interaction terms.

As shown in Table 3, the coefficient of CEO Duality is positive in all models and significantly positive in models (11)-(15), indicating that, on average, CEO duality is positively associated with firm performance, especially long-term performance. As for our main interest in the coefficients of the interaction terms between CEO duality and the three proxies for political influence, our findings show that, except for the models with one-year post-IPO performance as the dependent variable, all the other interaction terms are significant with the signs consistent with our predictions (hypotheses). Overall, the results suggest that the higher the extent of political influence, the benefit of CEO duality is less likely to outweigh the cost of CEO duality, at least for the listed firms in China.

Table 3. Multivariate Tests on Hypotheses.

\begin{tabular}{|c|c|c|c|c|c|c|c|c|c|c|}
\hline \multirow{2}{*}{ VARIABLES } & \multicolumn{5}{|c|}{ One-year Post-IPO Performance } & \multicolumn{5}{|c|}{ Two-year Post-IPO Performance } \\
\hline & (1) & (2) & (3) & (4) & (5) & (6) & (7) & (8) & (9) & (10) \\
\hline Constant & $\begin{array}{l}-0.084 \\
(0.384)\end{array}$ & $\begin{array}{l}-0.045 \\
(0.385)\end{array}$ & $\begin{array}{l}-0.098 \\
(0.382)\end{array}$ & $\begin{array}{l}-0.094 \\
(0.386)\end{array}$ & $\begin{array}{l}-0.067 \\
(0.386)\end{array}$ & $\begin{array}{l}1.372 * * \\
(0.455)\end{array}$ & $\begin{array}{l}1.439 * * \\
(0.460)\end{array}$ & $\begin{array}{l}1.342 * * \\
(0.450)\end{array}$ & $\begin{array}{l}1.312 * * \\
(0.459)\end{array}$ & $\begin{array}{l}1.348 * * \\
(0.459)\end{array}$ \\
\hline CEO Duality & $\begin{array}{l}0.051+ \\
(0.029)\end{array}$ & $\begin{array}{l}0.065 * \\
(0.031)\end{array}$ & $\begin{array}{l}0.077 * \\
(0.034)\end{array}$ & $\begin{array}{l}0.082 \\
(0.059)\end{array}$ & $\begin{array}{l}0.096 \\
(0.059)\end{array}$ & $\begin{array}{l}0.061 \\
(0.038)\end{array}$ & $\begin{array}{l}0.084 * \\
(0.040)\end{array}$ & $\begin{array}{l}0.117 * * \\
(0.044)\end{array}$ & $\begin{array}{l}0.234 * * \\
(0.083)\end{array}$ & $\begin{array}{l}0.261 * * \\
(0.083)\end{array}$ \\
\hline Regulated & $\begin{array}{l}0.132 * * \\
(0.036)\end{array}$ & $\begin{array}{l}0.165 * * \\
(0.039)\end{array}$ & $\begin{array}{l}0.126 * * \\
(0.036)\end{array}$ & $\begin{array}{l}0.132 * * \\
(0.036)\end{array}$ & $\begin{array}{l}0.155 * * \\
(0.040)\end{array}$ & $\begin{array}{l}0.170 * * \\
(0.048)\end{array}$ & $\begin{array}{l}0.228 * * \\
(0.055)\end{array}$ & $\begin{array}{l}0.158 * * \\
(0.048)\end{array}$ & $\begin{array}{l}0.169 * * \\
(0.048)\end{array}$ & $\begin{array}{l}0.201 * * \\
(0.057)\end{array}$ \\
\hline PC Top Mgr & $\begin{array}{l}-0.031 \\
(0.026)\end{array}$ & $\begin{array}{l}-0.033 \\
(0.026)\end{array}$ & $\begin{array}{l}-0.004 \\
(0.031)\end{array}$ & $\begin{array}{l}-0.030 \\
(0.026)\end{array}$ & $\begin{array}{l}-0.009 \\
(0.031)\end{array}$ & $\begin{array}{l}-0.045 \\
(0.035)\end{array}$ & $\begin{array}{l}-0.049 \\
(0.035)\end{array}$ & $\begin{array}{l}0.013 \\
(0.041)\end{array}$ & $\begin{array}{l}-0.044 \\
(0.035)\end{array}$ & $\begin{array}{l}-0.001 \\
(0.041)\end{array}$ \\
\hline State & $\begin{array}{l}-0.011 \\
(0.030)\end{array}$ & $\begin{array}{l}-0.009 \\
(0.030)\end{array}$ & $\begin{array}{l}-0.009 \\
(0.030)\end{array}$ & $\begin{array}{l}0.004 \\
(0.034)\end{array}$ & $\begin{array}{l}-0.002 \\
(0.034)\end{array}$ & $\begin{array}{l}-0.047 \\
(0.045)\end{array}$ & $\begin{array}{l}-0.044 \\
(0.045)\end{array}$ & $\begin{array}{l}-0.042 \\
(0.045)\end{array}$ & $\begin{array}{l}0.037 \\
(0.050)\end{array}$ & $\begin{array}{l}0.027 \\
(0.050)\end{array}$ \\
\hline Regulated*CEO Duality & & $\begin{array}{l}-0.118 \\
(0.082)\end{array}$ & & & $\begin{array}{l}-0.101 \\
(0.084)\end{array}$ & & $\begin{array}{l}-0.206^{*} \\
(0.100)\end{array}$ & & & $\begin{array}{l}-0.149 \\
(0.105)\end{array}$ \\
\hline PC Top Mgr*CEO Duality & & & $\begin{array}{l}-0.088 \\
(0.055)\end{array}$ & & $\begin{array}{l}-0.076 \\
(0.056)\end{array}$ & & & $\begin{array}{l}-0.191 * * \\
(0.073)\end{array}$ & & $\begin{array}{l}-0.154 * \\
(0.075)\end{array}$ \\
\hline State*CEO Duality & & & & $\begin{array}{l}-0.037 \\
(0.064)\end{array}$ & $\begin{array}{l}-0.013 \\
(0.066)\end{array}$ & & & & $\begin{array}{l}-0.211 * \\
(0.090)\end{array}$ & $\begin{array}{l}-0.169+ \\
(0.093)\end{array}$ \\
\hline Largest Ownership & $\begin{array}{l}-0.006 \\
(0.071)\end{array}$ & $\begin{array}{l}-0.001 \\
(0.072)\end{array}$ & $\begin{array}{l}-0.006 \\
(0.072)\end{array}$ & $\begin{array}{l}-0.008 \\
(0.072)\end{array}$ & $\begin{array}{l}-0.002 \\
(0.072)\end{array}$ & $\begin{array}{l}-0.067 \\
(0.090)\end{array}$ & $\begin{array}{l}-0.057 \\
(0.091)\end{array}$ & $\begin{array}{l}-0.067 \\
(0.090)\end{array}$ & $\begin{array}{l}-0.078 \\
(0.090)\end{array}$ & $\begin{array}{l}-0.068 \\
(0.091)\end{array}$ \\
\hline Market to Book Ratio & $\begin{array}{l}0.041 * * \\
(0.008)\end{array}$ & $\begin{array}{l}0.041 * * \\
(0.008)\end{array}$ & $\begin{array}{l}0.041 * * \\
(0.008)\end{array}$ & $\begin{array}{l}0.041 * * \\
(0.008)\end{array}$ & $\begin{array}{l}0.041 * * \\
(0.008)\end{array}$ & $\begin{array}{l}0.017 \\
(0.011)\end{array}$ & $\begin{array}{l}0.017 \\
(0.011)\end{array}$ & $\begin{array}{l}0.017 \\
(0.011)\end{array}$ & $\begin{array}{l}0.017 \\
(0.011)\end{array}$ & $\begin{array}{l}0.018 \\
(0.011)\end{array}$ \\
\hline Leverage & $\begin{array}{l}-0.001 \\
(0.010)\end{array}$ & $\begin{array}{l}-0.002 \\
(0.010)\end{array}$ & $\begin{array}{l}-0.000 \\
(0.010)\end{array}$ & $\begin{array}{l}-0.001 \\
(0.010)\end{array}$ & $\begin{array}{l}-0.001 \\
(0.010)\end{array}$ & $\begin{array}{l}-0.010 \\
(0.016)\end{array}$ & $\begin{array}{l}-0.012 \\
(0.017)\end{array}$ & $\begin{array}{l}-0.007 \\
(0.018)\end{array}$ & $\begin{array}{l}-0.009 \\
(0.017)\end{array}$ & $\begin{array}{l}-0.008 \\
(0.018)\end{array}$ \\
\hline Log of Assets & $\begin{array}{l}-0.003 \\
(0.019)\end{array}$ & $\begin{array}{l}-0.005 \\
(0.019)\end{array}$ & $\begin{array}{l}-0.003 \\
(0.019)\end{array}$ & $\begin{array}{l}-0.003 \\
(0.019)\end{array}$ & $\begin{array}{l}-0.005 \\
(0.019)\end{array}$ & $\begin{array}{l}-0.053 * \\
(0.022)\end{array}$ & $\begin{array}{l}-0.058 * \\
(0.023)\end{array}$ & $\begin{array}{l}-0.053 * \\
(0.022)\end{array}$ & $\begin{array}{l}-0.054 * \\
(0.023)\end{array}$ & $\begin{array}{l}-0.056^{*} \\
(0.023)\end{array}$ \\
\hline $\begin{array}{l}\text { Year Dummies } \\
\text { Adjusted R-squared }\end{array}$ & $\begin{array}{l}\text { yes } \\
0.063\end{array}$ & $\begin{array}{l}\text { yes } \\
0.065\end{array}$ & $\begin{array}{l}\text { yes } \\
0.065\end{array}$ & $\begin{array}{l}\text { yes } \\
0.062\end{array}$ & $\begin{array}{l}\text { yes } \\
0.065\end{array}$ & $\begin{array}{l}\text { yes } \\
0.067\end{array}$ & $\begin{array}{l}\text { yes } \\
0.071\end{array}$ & $\begin{array}{l}\text { yes } \\
0.074\end{array}$ & $\begin{array}{l}\text { yes } \\
0.074\end{array}$ & $\begin{array}{l}\text { yes } \\
0.080\end{array}$ \\
\hline
\end{tabular}

Table 3. Continue.

\begin{tabular}{|c|c|c|c|c|c|}
\hline \multirow{2}{*}{ VARIABLES } & \multicolumn{5}{|c|}{ Three-year Post-IPO Performance } \\
\hline & (11) & (12) & (13) & (14) & (15) \\
\hline \multirow[t]{2}{*}{ Constant } & $1.334 *$ & $1.436^{*}$ & $1.294 *$ & $1.258 *$ & $1.323 *$ \\
\hline & $(0.566)$ & $(0.568)$ & $(0.562)$ & $(0.571)$ & $(0.568)$ \\
\hline \multirow[t]{2}{*}{ CEO Duality } & $0.081+$ & $0.116^{*}$ & $0.153 * *$ & $0.298 * *$ & $0.334 * *$ \\
\hline & $(0.046)$ & $(0.049)$ & $(0.055)$ & $(0.106)$ & $(0.106)$ \\
\hline \multirow[t]{2}{*}{ Regulated } & $0.222 * *$ & $0.310 * *$ & $0.205 * *$ & $0.219 * *$ & $0.276 * *$ \\
\hline & $(0.060)$ & $(0.068)$ & $(0.060)$ & $(0.060)$ & $(0.070)$ \\
\hline \multirow[t]{2}{*}{ PC Top Mgr } & -0.039 & -0.045 & 0.035 & -0.038 & 0.015 \\
\hline & $(0.043)$ & $(0.043)$ & $(0.050)$ & $(0.043)$ & $(0.050)$ \\
\hline \multirow[t]{2}{*}{ State } & -0.081 & -0.076 & -0.074 & 0.025 & 0.011 \\
\hline & $(0.057)$ & $(0.057)$ & $(0.057)$ & $(0.066)$ & $(0.067)$ \\
\hline Regulated*CEO Duality & & $-0.316^{*}$ & & & $-0.245+$ \\
\hline
\end{tabular}




\begin{tabular}{|c|c|c|c|c|c|}
\hline \multirow{2}{*}{ VARIABLES } & \multicolumn{5}{|c|}{ Three-year Post-IPO Performance } \\
\hline & (11) & (12) & (13) & (14) & (15) \\
\hline & & $(0.126)$ & & & $(0.128)$ \\
\hline PC Top Mgr*CEO Duality & & & $\begin{array}{l}-0.245^{* *} \\
(0.088)\end{array}$ & & $\begin{array}{l}-0.193 * \\
(0.091)\end{array}$ \\
\hline \multirow[t]{2}{*}{ State*CEO Duality } & & & & $-0.265^{*}$ & $-0.207+$ \\
\hline & & & & $(0.114)$ & $(0.117)$ \\
\hline \multirow[t]{2}{*}{ Largest Ownership } & -0.036 & -0.021 & -0.036 & -0.049 & -0.034 \\
\hline & $(0.104)$ & $(0.104)$ & $(0.104)$ & $(0.104)$ & $(0.104)$ \\
\hline \multirow[t]{2}{*}{ Market to Book Ratio } & -0.008 & -0.007 & -0.007 & -0.007 & -0.006 \\
\hline & $(0.013)$ & $(0.013)$ & $(0.013)$ & $(0.013)$ & $(0.012)$ \\
\hline \multirow[t]{2}{*}{ Leverage } & $-0.052 *$ & $-0.055^{*}$ & $-0.049^{*}$ & $-0.051 *$ & $-0.051 *$ \\
\hline & $(0.022)$ & $(0.022)$ & $(0.023)$ & $(0.022)$ & $(0.024)$ \\
\hline \multirow[t]{2}{*}{ Log of Assets } & $-0.058^{*}$ & $-0.065^{*}$ & $-0.058^{*}$ & $-0.058^{*}$ & $-0.063^{*}$ \\
\hline & $(0.029)$ & $(0.029)$ & $(0.028)$ & $(0.029)$ & $(0.029)$ \\
\hline Year Dummies & yes & yes & yes & yes & yes \\
\hline Adjusted R-squared & 0.042 & 0.048 & 0.050 & 0.049 & 0.058 \\
\hline
\end{tabular}

Robust standard errors in parentheses. ${ }^{* *} \mathrm{p}<0.01,{ }^{*} \mathrm{p}<0.05,+\mathrm{p}<0.10 . \mathrm{n}=769$.

\section{Conclusion}

By investigating the post-IPO performance of Chinese firms, this paper empirically examines the role which political influence plays in the performance effect of CEO duality.

Prior contingency-based studies mainly focus on the situations under which unified decision-making is critical for a firm's success. However, the factors which influence the agency cost of CEO duality should be also taken into consideration. Our study is intended to fill this gap by considering political influence (proxied by regulation, state ownership and top manager's political connection) which is argued to mitigate competition (the competition which the firm faces in the market, and the competition which the CEO faces from other managers within the firm) and hence to exacerbate the problem of agency cost caused by CEO duality.

Consistent with our argument, we find that, on average, post-IPO performance is positively associated with CEO duality. But, such a positive association is less pronounced for state-controlled firms, for the firms in regulated industries, and for the firms with politically connected CEOs. Overall, our findings suggest that the higher is the extent of political influence, the benefit of CEO duality is less likely to outweigh the cost of CEO duality, at least for the listed firms in China. As for the implication for policy-makers, current practice requesting all listed firms to abolish CEO duality is solely based on the perspective of agency cost theory. Doing so fails to take into account the potential benefit of CEO duality, and may not be in the favor of minor shareholders.

To sum up this paper, we hope that our study would be a well marked step toward better understanding of the economic consequence of CEO duality both in general and in a transitional economy context in particular.

\section{References}

[1] Aggarwal R, Samwick A. 1999. Executive compensation, strategic competition, and relative performance evaluation:
Theory and evidence. Journal of Finance 54 (6): 1999-2043.

[2] Aharony J, Lee CW, Wong TJ. 2000. Financial packaging of IPO firms in China, Journal of Accounting Research 38 (1): 103-126.

[3] Alchian A. 1950. Uncertainty, evolution and economic theory. The Journal of Political Economy 58 (3): 211-221.

[4] Berg SV, Smith SK. 1978. CEO and board chairman: A quantitative study of dual vs. unitary board leadership. Directors \& Boards 3 (1): 34-37.

[5] Berl A, Means G. 1932. Modern corporation and private property. Macmillan Co. Press: New York

[6] Boyd BK. 1995. CEO duality and firm performance: A contingency model. Strategic Management Journal 16 (4): 301-312.

[7] Chen Z. H., Guan Y. Y., Ke B. 2009. Does Managerial Stock Option Compensation Increase Shareholder Value in State-Controlled Chinese Firms Listed in Hong Kong? Working Paper, Chinese University of Hong Kong

[8] Christie A., Joyce M., Watts R. 2003. Decentralization of the firm: Theory and evidence. Journal of Corporate Finance 9 (1): 3-36.

[9] Clarke DC. 2003. Corporate governance in China: An overview. China Economic Review 14 (4): 494-507.

[10] Dean T, Brown R. 1995. Pollution regulation as a barrier to new firm entry. Academy of Management Journal 38 (1): 288-303.

[11] Donaldson L. 1990. The ethereal hand: Organizational economics and management theory. Academy of Management Review 15 (3): 369-381.

[12] Donaldson L, Davis J. 1991. Stewardship theory or agency theory: CEO governance and shareholder returns. Australian Journal of Management 16 (1): 49-65.

[13] Fan J. P., Wong T. J., Zhang T. Y. 2007. Politically connected CEOs, corporate governance, and post-IPO performance of China's newly partially privatized firms. Journal of Financial Economics 84 (2): 330-357. 
[14] Fee A, Hadlock C. 2000. Management turnover and product market competition: Empirical evidence from the U. S. newspaper industry. The Journal of Business 73 (2): 205-243.

[15] Finkelstein S, D'Aveni RA. 1994. CEO duality as a double-edged sword: How boards of directors balance entrenchment avoidance \& unity of command. Academy of Management Journal 37 (5): 1079-1108.

[16] Firth M, Rui O, Fung P. 2006. Corporate governance and CEO compensation in China. Working Paper.

[17] Giroud X, Mueller H. 2008. Does corporate governance matter in competitive industries? Working Paper, New York University

[18] Griffin J, Mahon J. 1997. Corporate social performance and corporate financial performance debate: Twenty-five years of incomparable research. Business and Society 36 (1): 5-31.

[19] Gu Z. Y., Cao Y, Yang Y. 2010. Prolonged long-term incentives: A re-examination of the guidelines of executive equity ownership. Working Paper, Chinese University of Hong Kong.

[20] Hart O. 1983. Market mechanism as an incentive scheme. Bell Journal of Economics 14 (2): 366-382.

[21] Hovey M, Li L, Naughton A. 2003. The relationship between valuation and ownership of listed firms in China. Corporate Governance: An International Review 11 (2): 112-123.

[22] Jensen M. 1993. Modern industrial revolution, exit, \& the failure of internal control systems. Journal of Finance 6 (4): $4-23$.

[23] Jensen M, Meckling W. 1976. Theory of the firm: Managerial behavior, agency costs and ownership. Journal of Financial Economics 3 (4): 305-360.

[24] Kole S, Lehn K. 1997. Deregulation and the adaptation of governance structures: The case of the U. S. airline industry. Working Paper, University of Rochester.

[25] Maskin E. Y., Qian Y, Xu C. G. 2000. Incentives, information and organizational form. Review of Economic Studies 67 (2): 359-378.

[26] Masulis R, Wang C, Xie F. 2007. Corporate governance and acquirer returns. Journal of Finance 62 (4): 1851-1889.

[27] Nee V. 1992. Organizational dynamics of market transition: Hybrid forms, property rights, and mixed economy in China. Administrative Science Quarterly 37 (1): 1-27.

[28] Orlitzky MFL, Schmidt, Rynes S. L. 2003. Corporate social and financial performance: A meta-analysis. Organization Studies 24 (3): 403-441.
[29] Peng M. W., Zhang S, Li X. 2007. CEO duality and firm performance during institutional transitions. Management \& Organization Review 3 (2): 205-225.

[30] Rechner PL, Dalton DR. 1991. CEO duality and organizational performance: A longitudinal analysis. Strategic Management Journal 12 (2): 155-160.

[31] Schmidt K. 1997. Managerial incentives and product market competition. Review of Economic Studies 64 (2): 191-213.

[32] Shleifer A. 1985. A theory of yardstick competition. Rand Journal of Economics 16 (3): 319-328.

[33] Shleifer A, Vishny R. W. 1986. Large shareholders and corporate control. Journal of Political Economy 94 (3): 461-488.

[34] Shleifer A, Vishny R. W. 1994. Politicians and firms. Quarterly Journal of Economics 109 (4): 995-1025.

[35] Shleifer A, Vishny R. W. 1997. A survey of corporate governance. Journal of Finance 52 (2): 737-783.

[36] Song F, Yuan P, Gao F. 2006. Does large state shareholder affect the governance of Chinese board of directors? Working Paper, Tsinghua University.

[37] Stigler G. 1951. The division of labor is limited by the extent of the market. Journal of Political Economy 59 (3): 185-193.

[38] Stigler G. 1961. The economics of information. Journal of Political Economy 69 (3): 213-225.

[39] Tian J. J., Lau C. M. 2001. Board composition, leadership structure and performance in Chinese shareholding companies. Asia Pacific Journal of Management 18 (2): 245-263.

[40] Wang Q, Wong T. J, Xia L. 2008. State ownership, the institutional environment, and auditor choice: Evidence from China. Journal of Accounting and Economics 46 (1): 112-134.

[41] Wu S, Liu Z, Fan J. 2001. An empirical study of the relationship between non-executive directors and firm performance. China Industrial Economy (in Chinese) 9: 69-76.

[42] Yu D. Z, Gu L. R. 2002. Leadership structure of corporation and performance. China Industrial Economy (in Chinese), 2: 70-78.

[43] Dey A., Engel E., Liu X. 2014. CEO and board chair roles: To split or not to split? Working Paper, University of Chicago.

[44] Frydman C., Jenter D. 2013. CEO compensation. Working Paper, NBER. 